Dokuz Eylül Üniversitesi-Mühendislik Fakültesi

Fen ve Mühendislik Dergisi

Cilt 19, Sayı 57, Eylül 2017
Dokuz Eylul University-Faculty of Engineering Journal of Science and Engineering Volume 19, Issue 57, September 2017

DOI: $10.21205 /$ deufmd.2017195784

\title{
Tedarik Zinciri Yönetiminde Lojistik Kümelerin Önemi: Bolu İli İçin Uygulama
}

\author{
H. Giray REŞAT ${ }^{*} 1$ \\ 1İzmir Ekonomi Üniversitesi, Mühendislik Fakültesi, Endüstri Mühendisliği Bölümü, \\ 35330, İzmir
}

(Alınış / Received: 16.03.2017, Kabul / Accepted: 06.07.2017, Online Yayınlanma / Published Online: 20.09.2017)

Anahtar Kelimeler Lojistik, Kümelenme, Ölçme Değișmezliği
Özet: $\mathrm{Bu}$ çalışma ile birlikte Bolu ilinde faaliyet gösteren firmaların lojistik süreçlerindeki temel ihtiyaçlarının belirlenmesi ve yapılan iyileştirme çalışmalarının lojistik kümelenme faaliyetleri için önemi araştırılmıştır. Lojistik sektöründeki farklı oyuncularının bilgi paylaşımı, eğitim ve öğrenme kabiliyetlerini kullanarak kaynak ve kapasite paylașımı ve katma değerli hizmetlerin artırılması üzerine algılarının anket çalıșmaları ile elde edilen veriler doğrultusunda detaylı incelemesi yapılmıştır. Lojistik sektörüne yoğun etkisi olan farklı değişkenler kullanılarak çeşitli aşamalarda ölçme değişmezliği testleri yardımıyla verilerin analizinin yapılması ve bölge genelinde kümelenme faaliyetlerinin üçlü sarmal yapının paydașları için faydaları ortaya konulmuştur. Araştırma sonucunda şirketlerin sektör içerisindeki kapasite artışları veya firmaların çalışma yaşlarındaki artış çıktı değişkenleri üzerinde olumlu etkileri olduğu gözlenmiştir.

\section{The Importance of Logistics Clustering for Supply Chain Management: A Case Study of Bolu}

\begin{abstract}
Keywords Logistics,

Clustering,

Equivalent

Measurement

Abstract: This study investigates the importance of clustering activities in order to increase the quality and effectiveness of logistics industry, also shows the determination of basic needs and assessment of logistics processes for different stakeholders operating in Bolu. The effects of different stakeholders in logistics sector over capacity and resource sharing and increasing the value-added services by using the knowledge sharing, education and learning abilities are performed with the detailed analysis. The roadmap for the development of logistics sector and regional development is prepared by analyzing the data with equivalent measurement tests at various stages using different important variables and by sharing the importance of clustering activities for member of triple helix structures. As a consequence, the positive impact of capacity and maturity level increases of companies over the variables of the models is observed.
\end{abstract}




\section{Giriş}

Türkiye'nin jeo-stratejik konumu dolayısıyla ülke iç ve diş ticareti, kalkınma stratejileri ve ekonomisi açısından dış ticaret aktivitelerinin önemi her geçen gün biraz daha artmaktadır ve 2023 Türkiye İhracat Stratejisi ile 500 milyar ABD Doları ihracata ulaşarak dünya ticaretinde lider ülkeler arasında yer alması hedeflenmektedir [1]. Türkiye'nin dünya ihracatından aldığı payın \%1,5'e ulaşması ve dünyanın en büyük 10 ekonomisi arasında yer alması Ar-Ge, yenilik, ileri teknoloji ve bilgi odaklı üretim ve hizmet sektörleri ile mümkün olabileceği bu strateji planında net bir şekilde ortaya konulmuştur [1]. Lojistik sektörü üretimin her aşamasını, istihdamı ve bölgesel gelişimi etkileyerek ekonomide hayati bir rol oynamaktadır ve vatandaşların günlük yaşam koşullarına, kalitesine direkt olarak etki ederek, hizmet sektörünün önemli bir parçası haline gelmiştir. Son yıllarda görülen rekabet koşullarının güçleşmesi, küreselleşme, teknolojilerdeki hızlı değişimler, müşteri taleplerinin farklılaşması, tedarik zincirlerinin karmaşıklaşması şirketler için iç süreçlerin yeniden gözden geçirilmesi ve yeni stratejilerin belirlenmesi ihtiyacını ortaya çıkarmıştır [2]. Kalkınma planları çerçevesinde öngörülen temel amaç ekonomik ve sosyal yaşamın gerekleri ile uyumlu, dengeli ulaştırma politikaları ile ekonomik, emniyetli ve hızlı bir dış ticaretin gerçekleștirilmesidir. $\mathrm{Bu}$ amaç doğrultusunda çağdaş teknolojilerle desteklenmiş ve uluslararası düzenlemelerle uyum içinde mevcut lojistik altyapının geliştirilmesi hedeflenmiştir. Günümüz koşullarında gelişmekte olan lojistik sistemler tedarik zincirinin omurgası olarak ön plana çlkmaktadır ve ticari faaliyetlerin hızlanarak geliștirilmesinde çok önemli bir rol oynamaktadır. Yapılan işlerin verimliliğinden ekonomik kazanımlara, çevresel faktörlerden zaman yönetimine kadar çok değişkenli bir yapıda sisteme dâhil olarak ciddi oranda katma değer sağlamaktadır. Fakat son zamanlarda uluslararası standartların ticari faaliyetlerde yer bulması ve gelişen çevresel duyarlılık anlayışı firmalarında çevre konusunda ciddi yatırımlar ve önlemler almasına sebep olmuștur. Tedarik zincirinin her aşamasında (üretim, satış, satın alma, lojistik, vb.) ekonomik bir katma değer sağlayabilmek için çeşitli yeşil uygulamalar kullanılmaya başlanmıştır [3]. Özellikle tedarik zincirinin önemli bir parçası olan lojistik faaliyetlerin çevresel faktörler açısından sürdürülebilir bir mekanizma içerisinde geliştirilmesi, şirketlerin iç dinamiklerinin geliştirilerek küresel perspektifte bakış açısı kazanmaları sayesinde mümkün olmaktadır [4]. Ülkenin küresel rekabet gücünü artırabilmesi, dünya pazarlarında katma değeri yüksek ürünler ile söz sahibi olabilmesi ve mevcut dış ticaret yapısından kaynaklanan olumsuzlukları aşarak uzun dönemli, sürdürülebilir bir ekonomik büyüme sağlayabilmesi için lojistik altyapının geliştirilmesi gerekmektedir. Lojistik ilişkilerinin tespiti sayesinde sanayi ürünlerinin lojistiğinde maliyet ve zaman tasarrufu yapılması ve bu sayede firmaların daha iyi kalitede ve değerde hizmeti daha az maliyet ve çevresel etki ile üreterek rekabet seviyelerini artırma imkânları olacaktır. Her ne kadar lojistik hizmet sağlayıcılar yapmış oldukları operasyonların çevreye olan etkilerini; örneğin yoğun karbon salınımlarından kaynaklanan küresel ısınma, hava kirliliği, gürültü kirliliği, vb. biliyor olsalar dahi bu etkilerin azaltılmasına yönelik faaliyetler ilave maliyetler doğuracağından ötürü uygulamaktan kaçınmaktadırlar [5]. Pishvaee ve diğ. lojistik faaliyetlerin şirket süreçlerine dâhil edilmesinin oldukça zorlu ve zaman alıcı olduğunu ve bu sürecin ancak bütünleşik bir yapıda devlet teşvikleri ile 
yapılması gerektiğini vurgulamıştır [6]. Marshall'ın 1890 yılında ortaya atmış olduğu bütünleşik ekonomiler çalışmasından bu yana şirket-devlet işletme modelleri veya diğer bir ifade ile kümelenme faaliyetleri son derece hızl bir gelişim göstermiştir [7]. Porter çalışmasında kümelenmeyi "aynı sektörde faaliyet gösteren ve aynı hedef doğrultusunda birbirleri ile rekabet eden veya işbirliğinde bulunan şirketlerin belirli coğrafik bölgelerde yoğunlaşması" olarak tanımlamıştır [8]. Şekil 1'de de paylaşıldığı üzere günümüz koşullarında sanayiciler, eğitim kurumları ve devlet iştirakleri ortak bir paydada bir araya gelerek sektörün üretkenliğini ve verimliliğini artırarak, teknolojik işbirlikleri ve ortak hizmet üretimleri yaptıkları üçlü sarmal yapılar oluşmaktadırlar.

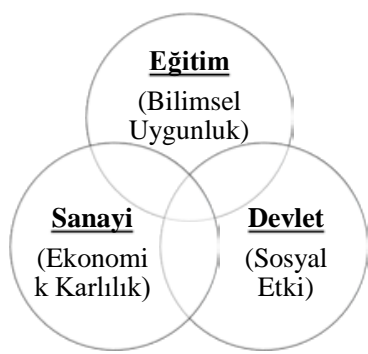

Şekil 1.Üçlü Sarmal Yapı ve Amaçları

Özellikle kümelenme modelleri hakkında literatürde çok sayıda çalışma bulunmaktadır. $[9,10]$ lojistik servislerin yaratmış olduğu katma değeri organizasyonel süreçler ve iş gücü arasındaki ilişkileri ortaya koyarak aktarmaya çalışmışlardır. [11, 12, 13] çalışmalarında lojistik süreçler için tanımlanmış olan performans göstergelerinin şirketlerin ve sektörün gelișimine olan etkilerini paylaşmış ve lojistik faaliyetlerin şirket süreçlerine ve stratejilerine olan etkilerini en üst seviyede sağlayabilmek için gerekli olan sistem tasarımlarına yer vermişlerdir. $[14,15]$ çalışmalarında lojistik yönetimlerin tedarik zinciri parçaları arasında meydana gelen bilgi ve malzeme akışının çeşitli sektör paydașları arasında nasıl uygulanması gerektiği konusunda bilgilendirme de bulunmuşlardır. Ayrıca, [16] kümelenme faaliyetlerinin lojistik sektörü için taşımacılık maliyetlerinin azalması, servis kalitesinin artırılması ve iș gücünün geliştirilerek kolay ulaşılabilir bir seviyeye gelebilmesi gibi faydalarından bahsetmiştir. [17, 18] raporlarında küme içerisindeki firmaların ortak hizmet satın alımları yaptıklarını ve gerekli durumlarda şirketlerin kısmi taşımacılık yerine kargolarını tek bir araçta birleștirerek ciddi maddi kazanımlar sağladıklarını belirtmiștir. Jing ve Cai kümelenme faaliyetlerine katılan firmaların müşteri portföylerine çok daha kolay ulaşarak belirli konularda uzmanlaşma sağlayabildiklerini ve bunun da müşteri memnuniyeti açısından firmalara ciddi faydalar sağlayacağını belirtmiştir [19]. Ayrıca Lam ve diğ. çalışmasında günümüz rekabetçi koşullarında müşterilerin özel taleplerinin olduğunu ve tek bir hizmet vermenin yeterli olmayacağından bahsetmiştir [20]. Müşteriden gelen özel siparişleri her zaman sağlayabilmenin çok kolay olmayacağını bu yüzden de küme içerisindeki diğer oyuncular ile ortak hizmet verilmesini teşvik edileceğini belirtmiştir. Özellikle müşterilerden gelen son katma değerli işlem (paketleme, etiketleme, promosyon ekleme, vb.) taleplerinin bütün lojistik firmalar tarafından karşılanamadığı ve bu sebepten ciddi müșteri kayıpları yaşayan firmaların küme içerisindeki diğer firmalardan bu hizmetleri satın alarak kombine bir hizmet verme imkanı sağlayabilmektedirler.

Kümelenme faaliyetleri direk mali boyutlarının yanı sıra firmalara başka açılardan da katkı sağlayabilmektedir. $[21,22]$ küme içerisinde yer alan teknoloji geliştiren firmalar sayesinde 
şirketlerin yönetim sistemlerinde, müşteri ve ürün takiplerinde, operasyonel konularda avantaj sağlayacakları hizmetleri çok daha hızlı ve düşük maliyetler ile ulaşabileceklerini belirtmişlerdir. [23, 24] firmaların küme içerisinde yer alan araştırma kurumları ile işbirliği yaparak eksik veya düzeltilmesi gereken süreçlerine yönelik çeşitli araştırma projeleri geliştirerek, yönetimlerini teorik ve bilimsel platformlara taşıma imkânları olduğunu belirtmiştir. [25, 26, 27] kümelenme faaliyetlerinin eğitim ve personel geliştirme programları üzerine olan faydalarından bahsetmişlerdir. Küme içerisindeki araştırma ve eğitim kurumları ile iș birliği içerisinde şirket ihtiyaçları doğrultusunda geliştirilecek olan eğitim programları ve staj programları sayesinde şirketlerin ihtiyaç duyduğu donanımlı ve süreçlere hâkim iş gücüne en kısa sürede ulaşma imkânı bulabilmektedirler. İlaveten, [28] şirketlerin mali kazanımlarının yanı sıra resmi kurumlar açısından da denetlenme, kontrol ve raporlama faaliyetlerinde küme içerisinde yer alan firmaların çok daha avantajlı olduklarını ve süreçlerini çok daha sistematik olarak yönettiklerini belirtmiștir. Diğer taraftan kümelenme modelinin her zaman şirketler açısından benzer ve eşit avantajlar sergilemeyeceği de tartışılmaktadır. Özellikle küme içerisinde faaliyet gösteren şirketlerin büyüklükleri, kapasiteleri, organizasyonel yapılanmaları firmalar arasındaki sınıf farklarını artırarak, büyük şirketlerin küme faaliyetlerinden çok daha büyük kazanımlar sağladıkları da gözlenmiştir [29]. Grando ve Belvedere küme içerisindeki küçük ve orta ölçekli firmaların yeni teknoloji ve eğitim programlarına yatırım yapamamalarından ötürü küme modelinin daha çok büyük ölçekli firmalar çevresinde kurulu olduğunu ve küçük ölçekli firmaların bu modele entegrasyonunda oldukça ciddi zorluklar yaşandığını belirtmiştir [30]. Ama bu konuda Soinio ve diğ. çalışmasında küçük ölçekli firmaların çok daha esnek ve hızlı karar verme süreçlerine sahip olmalarından ötürü büyük şirketlerin sağlamış oldukları faydalardan en üst seviye de faydalanabileceklerini belirtmiștir [31].

Türkiye'de her ne kadar lojistik sektörüyle ilgili ciddi yatırımlar yapılarak bu konuya özel bir önem verilse de halen lojistik sektörünün bu yatırımlar ve gelişmeler ile entegrasyonun nasıl yapılacağına dair detaylı ve teknik veriler ile desteklenmiş strateji ve eylem planları bulunmamaktadır. $\mathrm{Bu}$ durumda ülke genelinde kümelenme faaliyetlerinin önündeki en büyük engel olarak ortaya çıkmaktadır. Seçilen uygulama bölgesi olan Bolu ili, taşımacılık sektöründe Türkiye'nin en önde gelen marka illerinden birisi olma potansiyeline sahiptir. Çünkü bölgenin Türkiye Odalar ve Borsalar Birliği (TOBB) ve IRU (Dünya Karayolu Taşımacılığ $\quad$ Derneği) tarafından verilen TIR karnesi kullandırma yetkisi bulunmakla birlikte uluslararası taşımacılık işlemleri için TIR karnesi kullanan toplam 35 lojistik firması bulunmaktadır. Son üç yıllık (2013-2015) karne kullanım ortalamasına bakıldığında ise rakamın yaklaşık 15-16 bin adet olduğu görülmektedir [32] ve ayrıca Karayolları 41. şube şefliği verilerine göre Bolu Dağı Tüneli ve Bolu Dağı mevki üzerinden günde ortalama 18-19 bin civarı uluslararası ağır vasıta aracı geçmektedir [33]. Bu veriler bölge içerisinde faaliyet gösteren ve bölge üzerinden geçiş yapan lojistik firmaların yoğunluğunu ve büyüklüğünü göstermektedir. 2014-2023 Doğu Marmara Kalkınma Ajansı tarafından hazırlanan bölge planında da yer verildiği üzere bölgenin dış ticarette erişilebilirliğini artıracak lojistik altyapısının ve hizmetlerinin iyileştirilmesi gerekmektedir. Ayrıca 
Bolu'nun uzun vadede küresel rekabet gücünü ortaya koyabileceği ve uluslararası değer zincirinde yüksek katma değerli işlevler edineceği lojistik sektöründe uzmanlaşması ve bu sektörün geliştirilmesi de amaçlanmaktadır [34]. Hedefler doğrultusunda Bolu ilinin bu hızlı değişimine ayak uydurabilmesi ve il üzerinden geçen yoğun yük ve araç trafiğini artırarak daha verimli bir șekilde yönetilmesi amacıyla lojistik süreçleri için bütün unsurların katılımıyla sistemli bir plana ve stratejiye gereksinim olduğu gözlenmiştir. Bu doğrultuda bölge genelinde kurulacak olan lojistik kümesinin Bolu'ya bölgenin en önemli uluslararası lojistik kampüs özelliği kazandırılması beklenmektedir. Lojistik küme için gerekli çalışmalar yapılarak bölgenin uluslararası ve ulusal lojistik bağlantılarını en rasyonel altyapı ve bilgi işlem teknolojileriyle desteklenerek geliştirilmesi planlanmaktadır. $\mathrm{Bu}$ sayede lojistik faaliyetlerin kentin istihdamına ve ekonomisine katkısının artırılması, lojistik ara eleman ihtiyacının karşlanabilmesi için gereken eğitime ilişkin alt ve üst yapı ihtiyacının belirlenmesi sağlanacaktır. İlgili kümelenme modelinin faaliyete geçirilmesi sonucunda sektör paydaşlarının ve hedef yararlanıcıların ne tür bir fayda ve kazanım sağlayacakları aşağıdaki gibi özetlenmeye çalışılmıştır:

\section{Sosyal Faktörler Açısından Çıktılar:}

- Taşımacilık sektörüne ait gerek sektör içi gerekse özel alanlara hitap edecek teknolojik ihtiyaç ve gereksinimlerin tanımlanması

- Sektör paydaşları arasında (üçlü sarmal yapı) ortak bir bilgi ve tecrübe paylaşım kültürünün oluşturulması (ortak konular, modeller, diller, iyi uygulamalar, vb.)

- Taşımacilık sektörü genelinde daha çevreci ve sürdürülebilir bir bilincin oluşturulması ve gereksiz enerji ve insan gücü kayıplarının önlenmesi [26]

- Sektör genelinde teknolojik yatırımların artırılarak sürücü psikolojisi ve davranışları üzerinde iyileștirmeler yaparak bașta trafik kazalarını engelleyerek sektörün toplumsal yapıya katkıda bulunması

\section{Teknik ve Ekonomik Açıdan Çıktılar:}

- Araç sürücülerinin ve taşınan yüklerin güvenliğinde yaşanan sıkıntıların ortadan kaldırılması

- Şoförlerin rahat ve güvenli bir yolculuk yapmalarının sağlanabilmesi

- Lojistik firmalarının daha karlı, verimli, çevreci, müşteri şikâyetleri odaklı yönetim sistemleri kullanmaları [16]

- Spesifik ölçüm ve metot ile sektörün detaylı analiz edilmesi ve ortak ihtiyaçların en doğru şekilde tanımlanarak sektör oyuncularına minimum maliyetle sunulması [17]

- Yüksek katma değerli hizmet ürünlerinin tasarlanması ve üretilmesi

- Teknolojik ve operasyonel ihtiyaçların araştırma ve geliştirme tabanına dayandırılarak hızlı ve farklılaştırılarak sağlanması

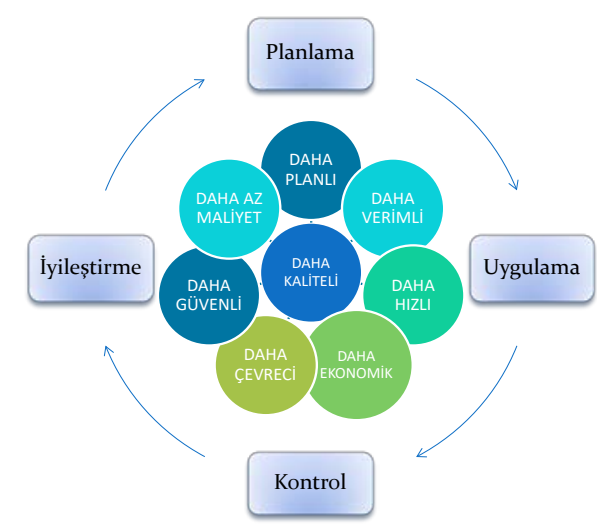

Şekil 2.Sürdürülebilir tedarik zincirinin çevre, ekonomi ve sosyal faktörlerle ilişkileri

Şekil 2'de yer verildiği üzere teknik, ekonomik ve sosyal açıdan çıtıların sektörün ihtiyaçlarını karşılayacak 
şekilde devamlı bir iyileştirme döngüsü kapsamında takibinin yapılması beklenmektedir. $\mathrm{Bu}$ sayede kurulacak olan küme modelinin verimliliği ve işlevselliği takip edilebilecektir. Çalışmanın temel amacl, Bolu ili kapsamında sunulan lojistik hizmetin verim ve kalitesini yükseltmek, firmaların lojistik süreçlerindeki temel ihtiyaçlarının belirlenmesi, planlanması, gerçekleștirilmesi ve etkinliklerinin değerlendirilmesi için esaslar oluşturulmasıdır. Ayrıca sürdürülebilir, çevreci bir lojistik sistem için zemin oluşturularak firmaların tedarik zincirlerine önemli bir katkı sağlamaktır. Bunun için düzenlenen anketlerden elde edilen veriler doğrultusunda sektör paydaşları arasında lojistik sektörü üzerinde yoğun etkisi olan farklı değişkenler kullanılarak çeşitli aşamalardaki ölçme değişmezlikleri yardımıyla verilerin analizinin yapılması ve bölge genelinde kümelenme faaliyetlerinin sektör için faydaları ortaya konularak sektörün gelişmesi için gerekli olan çıtıların araştırılması amaçlanmıştır.

Bu çalışma 5 bölümden oluşmaktadır. 2 . Bölümde araştırmada kullanılan model ve hipotezler hakkında detaylı bilgilendirmede bulunulmuştur. 3 . Bölümde veri toplama ve analizleri için kullanılan metodolojiye yer verilmiștir. 4 . Bölümde ise araştırmanın çıktılarına ve detaylı analiz sonuçları paylaşılmıştır. Son bölümde ise elde edilen sonuçlar değerlendirilmiş ve sonraki çalışmalar hakkında bilgi paylașılmıştır.

\section{Materyal ve Metot}

$\mathrm{Bu}$ bölümde tedarik zinciri içerisinde lojistik faaliyetleri etkileyen ve şirketlerin sunmuş oldukları hizmetin kalitesi ve verimliliği üzerinde etkisi olan temel problem ve sorunlar analiz edilmektedir. $\mathrm{Bu}$ amaç doğrultusunda geliştirilecek modele ait değişkenler ve hipotezler detaylı bir şekilde açıklanmaktadır. Kurulacak model sayesinde firmaların lojistik süreçlere olan yaklaşımları ve operasyonlarını etkileyen değișkenlerin hipotezler aracılığıyla analizleri yapılacaktır. $\mathrm{Bu}$ sayede firmaların temel lojistik ihtiyaçlarının belirlenmesi, planlanması, gerçekleștirilmesi ve etkinliklerinin değerlendirilmesi yaplacak ve geliştirilmeye açık alanlar tespit edilecektir.

Araştırma modelinde girdi değişkeni olarak tanımlanan 7 farklı kavram örneklemden elde edilen bilgiler ışı̆̆ında belirlenmiştir. $\mathrm{Bu}$ değișkenler özellikle sektör oyuncularının hizmet kalitesi ve verimliliği üzerinde etkisi olacağını düşündüğü kavramlar olarak ön plana çıkmıștır. Aynı şekilde modelin çıktı değişkenleri ise sektörün uluslararası platformda rekabet seviyesini artırmaya yarayacak faktörler olarak tespit edilmiştir.

Şekil 3'de belirtilmiş olduğu üzere araștırma modeli 3 ana çıtı değișkeni, 2 ara katman ve 7 girdi değişkeni olacak şekilde tasarlanmıștır.

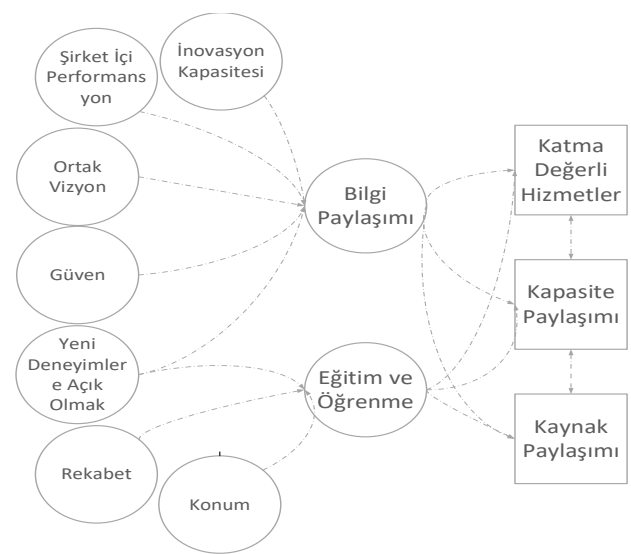

Şekil 3.Araştırma Modeli

$\mathrm{Bu}$ model sayesinde firmaların katma değerli hizmet üretimi, kapasite ve kaynak paylaşımı konuları üzerine etkisi olan çeşitli değişkenlerin analizi 
yapılacaktır. Firmaların çıktı değerleri üzerine etkisi olan 7 farklı girdi değişkeninin (yenilik, şirket içi performans, ortak vizyon, güven, yeni deneyimlere açık olmak, rekabet ve konum) bilgi paylaşımı ve eğitim/öğrenme süreçleri aracıllğıyla analizleri yapılmaktadır. Modele ait temel araștırma sorusu 7 farklı girdi değişkeninin şirketlerin katma değerli hizmet üretimine ve kapasite/kaynak paylaşımı üzerine nasıl bir etkisi vardır şeklinde düşünülmüştür. $\mathrm{Bu}$ sorunun cevabını araștırmak için aşağıda yer verilen 8 alternatif çift yönlü hipotez oluşturulmuştur.

\section{Bilgi Paylaşımı}

Hipotez 1: İnovasyon kapasitesi firmaların bilgi paylaşımını olumlu yönde etkiler.

Firmaların sahip oldukları araştırma/geliştirme (Ar-Ge) kapasiteleri ve yetkinliklerinin küme modelindeki firmalar arasındaki bilgi paylaşımını olumlu yönde etkilediği öngörülmektedir. Firmaların sahip oldukları Ar-Ge, iş geliştirme departmanları şirketin ihtiyaç duyduğu teknoloji ve yatırımları hızlı ve doğru bir şekilde tanımlamaya ve bu ihtiyacın giderilmesi için gerekli olan araştırmaları yapmaktadır. Bu süreçte firmaların Ar-Ge yapıları kuvvetlendikçe diğer firmalara yönelik çeşitli danışmanlık faaliyetleri sürdürebilmektedir veya dıșarıdan hizmet satın alabilmek için bu konuda tecrübeli firmalara yönelmektedirler. Tüm bu süreçler firmalara yoğun bir işbirliği ve bilgi paylaşımı ihtiyacı meydana getirmektedir.

Hipotez 2: Yeni deneyimlere açık olmak firmaların bilgi paylaşımını olumlu yönde etkiler.

Küme içerisindeki firmaların birbirleri ve diğer kümeler ile iletişim içerisinde olması ve bilgi transferini gerçekleștirmesi kümelenme modelleri için son derece önemli bir parametredir. $\mathrm{Bu}$ yapının kurulmasındaki en önemli ölçüt ise firmaların güncel gelişmelere ve trendlere ayak uydurarak yeni yatırımlara açık olmasıdır. Bu sayede firmalar çağdaş ve güncel teknolojileri/sistemleri kendi tesislerine, firmalarına ve süreçlerine entegre ederek yoğun rekabet ortamında kendilerine avantajlı bir konum yaratabilmektedirler.

Hipotez 3: Şirket içi performansın artması firmaların bilgi paylaşımını olumsuz yönde etkiler.

Firmaların kendi iç süreçlerindeki ve hizmet performanslarındaki iyileştirmeler firmalar açısından bir özgüven kaynă̆ı oluşturmaktadır ve firmaların işbirliği ve bilgi paylaşımı konusunda biraz daha kapalı bir yapıya dönüşmesine neden olmaktadır. $\mathrm{Bu}$ durumdaki firmaların zaten pazarda güçlü bir konumda olması ve ciddi bir araştırma kabiliyetinin olması bilgi transferi konusunda bu firmaları olumsuz etkilemektedir. Bu tip firmaların sistemsel bilgilerinin çalınması ve rekabet seviyelerinin korunması açısından bilgi paylaşımına çok sıcak bakmamaktadırlar.

\section{Hipotez 4: Ortak vizyon firmaların bilgi} paylaşımını olumlu yönde etkiler.

Küme içerisindeki firmaların sahip oldukları bakış açıları ve yol haritaları firmaların kendi aralarındaki bilgi transferi süreçlerini hızlandırmaktadır. Yeni bir pazara hizmet vermek isteyen firmaların veya sektörün sahip olduğu temel bir problemden şikayet duyan ve bir an önce çözüme kavuşturmaya çalışan firmalar bu doğrultuda en üst seviyede işbirliği ve bilgi transferi yapmaktadırlar.

Hipotez 5: Güven firmaların bilgi paylaşımını olumlu yönde etkiler. 
Küme içerisindeki firmaların bilgi paylaşımı açısından en büyük engelleri firmaların bir birlerine olan güven ortamıdır. Çünkü rekabet yoğun bir ortamda hizmet vermeye çalıșan firmaların bilgi güvenliği, şirketleri bünyesindeki eğitimli ve tecrübeli çalışanların rakip firma tarafından transfer edilmesi, müşteri şikâyetleri firmaların güven ortamı olușturmadaki en büyük engelleridir. Bu bağlamda, tam teșekküllü bir yönetim sistemi altında oluşturulacak bir güven ortamı firmaların kendi arasındaki bilgi paylaşımlarını hızlandırarak olumlu bir etki yaratacaktır.

\section{Eğitim ve Öğrenme:}

Hipotez 6: Yeni deneyimlere açık olmak firmaların ögrrenme yetilerini olumlu yönde etkiler.

Özellikle şirketlerinin süreçlerinde yer alan eksiklikleri veya süreçlerin iyileștirilmesi için güncel gelişmeleri ve yenilikçi uygulamaları takip eden firmaların öğrenme, araștırma-geliștirme yönlerinin çok daha gelişmiş olduğu beklenmektedir. Çünkü yeniliklere ulaşabilmenin en kolay yolu güncel teknolojileri ve araştırma kuruluşlarıyla sıkı işbirlikleri ile mümkün olmaktadır.

Hipotez 7: Rekabet firmaların ögrrenme yetilerini olumlu yönde etkiler.

Yoğun rekabet koşulları firmaları süreçlerinde ve hizmetlerinde çeșitlilik sağlamaya ve farklılaşmaya yöneltmektedir. Bu durumda yeniliklerin takip edilmesi ve yoğun araştırmalar ile mümkün olmaktadır ve firmaların öğrenme kapasitelerini artırmaya teşvik etmektedir.

Hipotez 8: Konum firmaların öğrenme yetilerini olumlu yönde etkiler.
Küme içerisinde yer alan firmaların konumlanmaları ve yakınlıkları birbirleri ile olan iletişimlerini ve işbirliklerini artırmaktadır. Özellikle eğitim ve araştırma kurumlarına yakın firmaların temel ihtiyaçlarının veya problemlerinin giderilmesi için ivedilikle eğitim kurumlarına ulaștıkları düşünülmektedir. Ayrıca yine lokasyon olarak yakın olan firmaların ortak hizmet alım/verme süreçlerinde daha yüksek oranda işbirliği içerisinde oldukları ve bu dayanışma modelinin ise firmaların öğrenme süreçlerini hızlandırdığı beklenmektedir.

Tüm bu eğitim ve öğrenim, bilgi paylaşımı faaliyetlerinin küme modeli üzerinde ciddi katkılarının olduğu öngörülmektedir. Küme içerisindeki firmaların kapasite ve kaynak paylaşımlarından, katma değerli hizmet üretmesine kadar iyileştirmelerde bulunduğu ve aralarında önemli bağların olduğu düşülmektedir. Artan firmalar arası ilişkiler kümenin verimliliği ve yenilik seviyelerini en üst düzeye çekerek katma değerli hizmetlerin üretilmesine, yeni ürün/hizmetlerin geliştirilmesine yol açmaktadır. Küme içerisindeki kaynakları (kalifiye personel, teknik ekipman, vb.) paylaşımı yine şirketlerin bilgi paylașımı ve eğitim seviyelerinin artması ile mümkün olmaktadır. Bu durumda yüksek personel maaşlarından, daha verimli operasyonel süreçlere; artan iş imkânlarından altyapısal iyileştirmelere kadar çok önemli katkılarda bulunmaktadır. Ayrıca, firmaların mevcut altyapılarını ve kapasitelerini diğer sektör oyuncuları ile paylaşmaları da sektör ve kümenin devamlılı̆̆ açısından önemli bir konudur. Özellikle, bilgi paylaşımı ile gelişim gösterecek olan bu kriter şirketlerin süreçlerinin daha verimli ve kolay yönetebilme imkanı tanımaktadır ve ciddi ekonomik kazanımlar sağlamaktadır. 
Küme içerisindeki büyük ölçekli firmaların kapasite, kaynak paylaşımına küçük ölçekli firmalara nazaran daha fazla eğilimi olduğu düşünülmektedir.

\section{Metodoloji}

$\mathrm{Bu}$ bölümde araștırmanın modeli kapsamında kullanılacak olan çalışma gruplarının, veri toplama araçları ve toplanan verilerin analizinde kullanılan istatistiksel tekniklere yer verilmiştir. Tedarik zinciri süreçleri içerisinde lojistik faaliyetlerinin maliyet oranı yaklaşık olarak satış maliyetlerinin 29.4\%'ü civarındadır [24] ve bu çalışma kapsamında pilot bölge olarak seçilen Bolu iline ait 2015 yılı reel diş ticaret rakamın 862 Mil. €'dur [35]. Bu ticaret hacmi göz önüne alındığı takdirde toplam lojistik maliyeti yaklaşık olarak 253 Mil. € (862 Mil. €*0,294) civarında olduğu öngörülmektedir. Bu rakama çevre illerden de gelebilecek talep eklendiğinde lojistik faaliyetler için yaklaşık 400-450 Mil. € civarında bir pazar büyüklüğü ortaya çıkacağı öngörülmektedir. $\mathrm{Bu}$ rakam ise bölge genelinde lojistik faaliyetlerin ne kadar ciddi bir öneme sahip olduğunu ortaya çıkarmaktadır.

Projenin saha analizleri sürecinde Bolu Sanayi ve Ticaret Odasının kapasite raporlarında belirlenmiş Bolu ili kapsaminda ithalat veya ihracat yapan sanayi kuruluşları, Uluslararası Nakliyeciler Derneğine kayıtlı uluslararası lojistik hizmeti veren şirketler, yükseköğrenim kuruluşları ve bazı kamu kuruluşları analiz kapsamına alınmıştır. İlgili sektör paydaşlarına ulaşılarak lojistik süreçlerde yaşamış oldukları operasyonel ve taktiksel seviye de problemleri ve operasyon süreçlerinde ortaya çıkan temel ihtiyaçları hakkında kendilerinden çeşitli bilgiler ve öneriler toplanmıştır. Bu çalışmanın temel amacı bölgedeki sektör paydaşlarının tedarik zincirlerini en çevreci ve optimum şekilde yönetebilmeleri ve tüm müşterilerin sorunlarına çözüm yaratabilecek şekilde sistem tasarımının yapılması için belirli bilgilerin toplanarak analizlerinin yapılmasıdır. Yapılan saha ziyaretleri ve literatür çalışmaları doğrultusunda Bolu ili kapsamındaki hedef sektör paydaşlarından lojistik süreçlerindeki ihtiyaçları hakkında bilgi toplamak amacıyla bazı anketler hazırlanmıștır ve firmalardan gerekli veriler elde edilmiştir. Veri toplama süresince firmaların sahipleri ve var ise dıș ticaret veya lojistik bölüm yöneticileri ile iletişime geçilerek mevcut süreçlerinin iyileştirilmesi ve yurt dışındaki en iyi örneklere yaklaştırabilmek amacıyla bir takım görüşmeler yapılmıștır. $\mathrm{Bu}$ görüșmeler sonucunda politika yapıcılar için lojistik faaliyetler bazında rekabetçiliği etkileyen unsurların kaldırılmasına ilișkin uzman görüșü yaklaşımı temel alınarak analizler yapılmıştır. Analizlerin uygulanma sürecinde kümelenme modeli açısından büyük önem arz eden sektör paydaşlarının konumlanması, müșteri talepleri ve firmaların yapmış oldukları ithalat ve ihracat miktarları göz önüne alınmıștır. Ancak, araștırma kapsamında örneklem büyüklüğü, zaman yetersizliği ve maliyet faktörü nedeniyle anketlerin önemli bir bölümü e-mail aracilığıyla katılımcilara doldurtulmuştur. $\quad \mathrm{Bu}$ durumda çalışmanın hem geri dönüş oranının düşük olması hem de katılımcıların hangi ortam ve nasıl doldurduklarına dair önemli bir kısıtı ortaya çıkarmaktadır.

Bolu ilindeki diş ticaret yapan firmaların lokasyon dağılımlarına bakıldığı takdirde çok dağınık olmadığı ve bir kaç bölge de kümelendikleri Şekil 4'de gözlenmektedir. Şekil 4'de yer alan kırmızı yıldızlar Bolu ilinde üretim yapan fakat merkez ofisleri Bolu dışında olan büyük ölçekli firmaları göstermektedir ve bu firmalar dış ticaret işlemlerini 


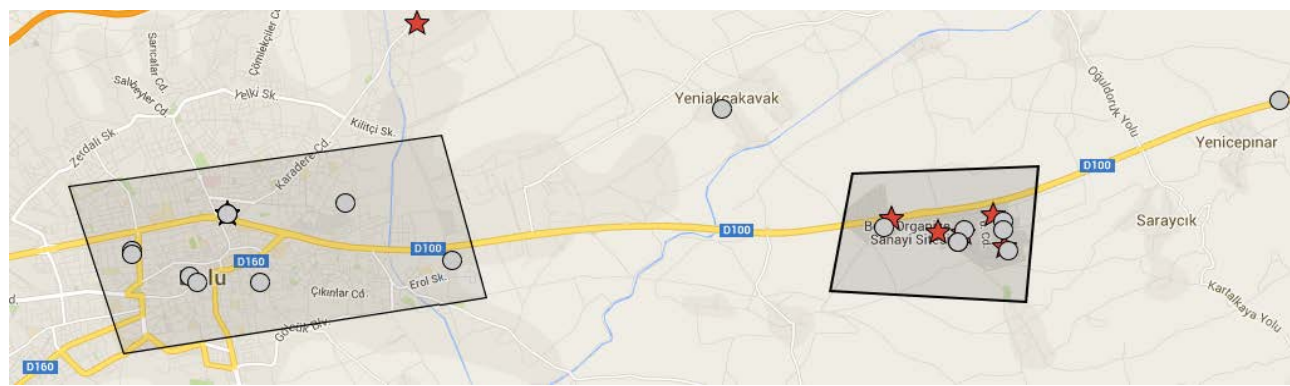

Şekil 4.Bolu'da faaliyet gösteren ve diș ticaret yapan firmaların lokasyonları [36]

\subsection{Veri Toplama ve Örnekleme}

Bolu ili kapsamında gerçekleştirilen çalışmada kullanılan anket hazırlama ve uygulama süreci Şekil 5'de yer verilmişti. Çalışmada istatiksel analizlerin yapılabilmesi için gerekli olan veri şirket ziyaretleri kapsamında yapilan görüşmeler ve anket tekniği ile sektör paydaşlarından elde edilmiştir. Anket soruları hazırlanmadan önce uygulamanın yapıldığı firmalarda ön incelemelerde bulunulmuş ve sektör temsilcileri ile görüşmeler düzenlenmiştir. $\mathrm{Bu}$ görüşme ve gözlem sonuçlarından elde edinilen bilgi, konu hakkında yapılan daha önceki literatür taramaları [11 - 13, 21, 22] ve sektör raporları [33, 34] kullanılarak araştırmada kullanılan anketler düzenlenmiştir. $\mathrm{Bu}$ anketlerin hazırlanma sürecinde dikkate alınan en önemli hususlar şirket bünyesinde ve bölge genelinde hizmet kalitesinin, verimliliğinin ve etkinliğinin artırılmasıdır. Firmaların yönetim anlayışlarının ve çalışma kapasitelerinin modern yönetim anlayışları ve teknikleri ile geliştirilmesi, iyileștirilmesini ve analiz edilmesine olanak sağlamaktır.

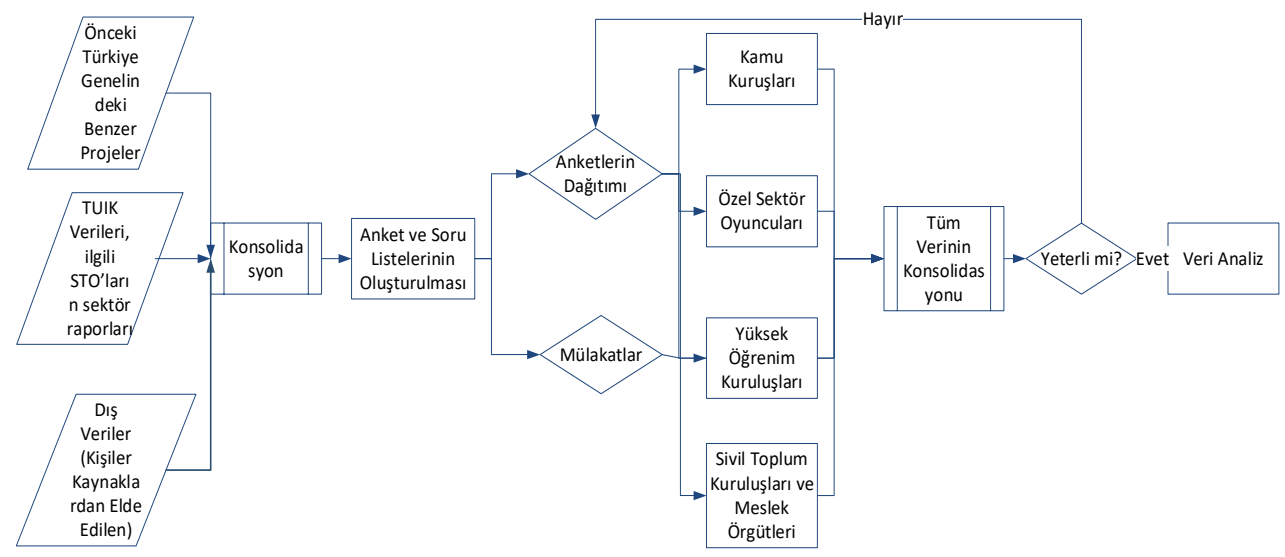

Şekil 5.Anket Hazırlama ve Uygulama Süreç Akıș Şeması

$\mathrm{Bu}$ anket çalışmasının amacı, uygulanacak bölge kapsamında sunulan hizmetin verim ve kalitesini yükseltmek, firmaların lojistik süreçler hakkında görüşlerini alarak geliştirilmeye açık alanların ve sektöre ait temel problemleri/sorunları analiz etmektir. Bu doğrultuda geliştirilen anket soruları, sektör oyuncularının özellikle tașımacılık alanındaki altyapısal problemlerin ve 
araç/gümrük tabanlı bürokratik sorunların da irdelenmesi konusunda vermiș oldukları önemli geri dönüşler ile zenginleștirilmiştir.

Görüşme ve anketlerde üzerinde durulan konu başlıkları dört gruba ayrılmıştır ve temel konu başlıkları şunlardır:

- Ankete katılan șirketlere ilișkin bilgiler: çalışan sayısı, kuruluş yılı, lojistik faaliyetler, hizmet verilen sektörler

- Firmaların faaliyetleri sırasında lojistik hizmetlerinde karşılaştıkları altyapı ve işletme sorunları.

- Bolu'nun bulunduğu coğrafyada (Balkanlar, Kafkasya, Ortadoğu) bölgesel bir lojistik merkez olma potansiyelinin tartışılması

- Yatırımciların Bolu'da yatırım yapma nedenleri

Anket soruları firmalar hakkında temel bilgilerin temin edilmesinden sonra likert ölçekleme metodu [43] kapsamında kısa, net ve anlaşılır biçimde tasarlanmış ve çoklu seçenekli olarak hazırlanmıştır. $\mathrm{Bu}$ anketler uygulanan kurumun durumuna göre soruların 1 ile 5 arasında değişen bir önem ölçeğinde (1=önemsiz/etkisiz, 2=çok az önemli, $5=$ önemli, vb.) değerlendirilmesi istenmiştir. Anketler 570 sektör paydaşı ile mail ortamında ve yüz yüze görüşmelerde paylaşılmış olup, 473 adet geri dönüş sağlanmıştır ve anket sonuçları sorulan soruların niteliğine uygun olan istatistik yöntemler (frekans, ortalama ve ki-kare) kullanılarak çözümlenmiş ve sonuçlar tablolar halinde paylaşılmıştır.

\subsection{Veri Analizi}

Lojistik sektöründe kümelenme faaliyetlerinin etkilerinin analiz edildiği çalışmada elde edilen veriler detaylı bir denetimden geçirildikten sonra IBM SPSS İstatistik sürüm 20.0 paket programında değerlendirilerek regresyon analizleri çizelgeler halinde gösterilmiştir [37]. Verilerin çözümlenmesinde firmaların şirket bilgilerine ait değişkenleri (sektör, çalışan sayısı, vb.) frekans ve yüzde dağılımları bulunarak tanımlayıcı istatistikler elde edilmiștir. Ki-kare $\left(X^{2}\right)$ değerleri hesaplanarak ilişkinin anlamlı olup olmadığı istatistiksel olarak test edilmiştir. Değişkenlere ait çoklu ölçümlerde uyumluluk düzeyi değerlendirmeleri güvenilirlik ölçümleri için oldukça önemlidir. $\mathrm{Bu}$ bağlamda Cronbach Alpha düzeyi $(\alpha)$ yapılan testlerdeki anlamlılık düzeyinin ölçülmesi için kullanılan yaygın değerlerden bir tanesidir [38] ve test senaryolarında bu değer $(\alpha) 0.05$ olarak kullanılmıştır. Ayrıca, ölçme değişmezliği testlerine ait model karşılaştırmalarında genellikle, CFI (Karşılaştırmalı Uyum İndeksi) ve RMSEA (Yaklaşım Hatası Ortalama Karekök) uyum değerleri kullanılmaktadır ve her ikisinin gruplar arası karşılaștırmalarda tutarlı bir șekilde sonuç verdikleri görülmüștür [39, 40].

Araştırmada sonuçların analiz sürecinde ölçme değişmezliği testleri kullanılmıştır. Çünkü gruplar arası karşılaştırma araştırmalarının temel amacının, araştırmalarda kullanılan ölçümlerin gruplar arası eşitsizliğin ortadan kaldırılmasıdır. Bu sebepten ilgili ölçme değişmezliği testleri üç farklı aşamada ele alınmıştır. Yapısal değişmezlik, her grup için faktör yükleri eșit olarak kabul edilir ve gruplar arası karşılaştırmalarda gruplar için her faktör aynı değişken olarak modele alınır [41]. İkinci olarak ise metrik değişmezlik testi kullanılmıştır. $\mathrm{Bu}$ testte uygulanan soruların tüm katılımcılar tarafından farklı zaman dilimlerinde aynı şekilde anlaşılıp anlaşılmadığı kontrol edilmiştir. $\mathrm{Bu}$ test eğer her hangi bir kısıt modelden çıkarıldığında sonuçlarda bir değişiklik meydana gelmiyorsa kullanılabilmektedir [42, 43]. Skalar değişmezlikte, gruplar arasındaki gizil değişkenlerin ortalama farklılıklarını değerlendirmek için önemlidir. 
Yapılan çalışmada yapısal eşdeğerlik, metrik eşdeğerlik, skalar eşdeğerlik sonuçları, RMSEA ve CFI uyum indeksleri ile ki-kare farklılık testi $\left(X^{2}\right)$ ve serbestlik derecesinin farklılığı $(S D)$ bakımından 0.05 anlamlılık düzeyine göre incelenmiștir. Buna göre, göreceli ki-kare indeksinin $\left(X^{2} / S D\right.$ oranı) 2 veya daha küçük bir değer olması gerektiği ve bu sayede ki-kare değerinin örnek büyüklüğünden bağımsız hale geldiğini öngörülmektedir. Ayrıca, RMSEA değerinin 0.05 veya daha küçük bir değer olması ve CFI değerinin ise 0.95 ve üzeri olması modelin veri seti ile daha güçlü uyum içinde olduğunu göstermektedir [44].

Tablo 1.Anket Dağılım Sayıları ve Oranları

\begin{tabular}{|c|c|c|c|c|c|c|c|c|}
\hline \multirow{2}{*}{$\begin{array}{c}\text { MAD } \\
\text { Gönderilen } \\
\text { Anket Sayısı }\end{array}$} & \multicolumn{2}{|c|}{$\begin{array}{c}\text { Lojistik Hizmet } \\
\text { Sağlayıcı }\end{array}$} & \multicolumn{2}{|c|}{$\begin{array}{c}\text { Lojistik } \\
\text { Hizmet Alıcı } \\
\end{array}$} & \multicolumn{2}{|c|}{$\begin{array}{c}\text { Eğitim } \\
\text { Kurulușları }\end{array}$} & \multicolumn{2}{|c|}{$\begin{array}{c}\text { Kamu } \\
\text { Kuruluşu }\end{array}$} \\
\hline & 274 & $48 \%$ & 285 & $50 \%$ & 5 & $1 \%$ & 6 & $1 \%$ \\
\hline $\begin{array}{c}\text { Cevaplanan } \\
\text { Anket Sayısı }\end{array}$ & 244 & $52 \%$ & 217 & $46 \%$ & 4 & $1 \%$ & 5 & $1 \%$ \\
\hline $\begin{array}{c}\text { İşlenebilir } \\
\text { Anket Sayısı }\end{array}$ & 211 & $54 \%$ & 174 & $44 \%$ & 4 & $1 \%$ & 5 & $1 \%$ \\
\hline
\end{tabular}

Tablo 1'de veri analizinde kullanılan anketlerin dağıtım ve sektör paydaşları tarafından geri dönüș yüzdelerine yer verilmiştir. Veri analizinde kullanılmak üzere toplamda 570 sektör paydaşına anketler dağıtılmıştır ve 473 adet sektör paydaşlarından geri dönüş sağlanabilmiştir. Gerekli ön incelemelerden ve anket sorularının \%50'sinden daha azının cevaplandığı anketler elendikten sonra toplam işlenebilir anket sayısı 394 adet olarak belirlenmiştir. Tablo 1'den de görüldüğü üzere ilk gönderilen anket dağılımı ile ișleme alınan anketlerdeki dağılımlar arasında ciddi bir farklılık olmamakla beraber, lojistik hizmet sağlayıcıların anketlerdeki ağırlığı bir miktar artmıştır (\%48'den \%54'e). Șekil 6'da da anket sorularının kategorize edilmiş hallerinin firmalara ve ankete katılım gösteren oyuncuların operasyonları üzerine etkilerinin değerlendirildiği (en düşük(1) - en yüksek (5)) ortalama değerler yer almaktadır. 


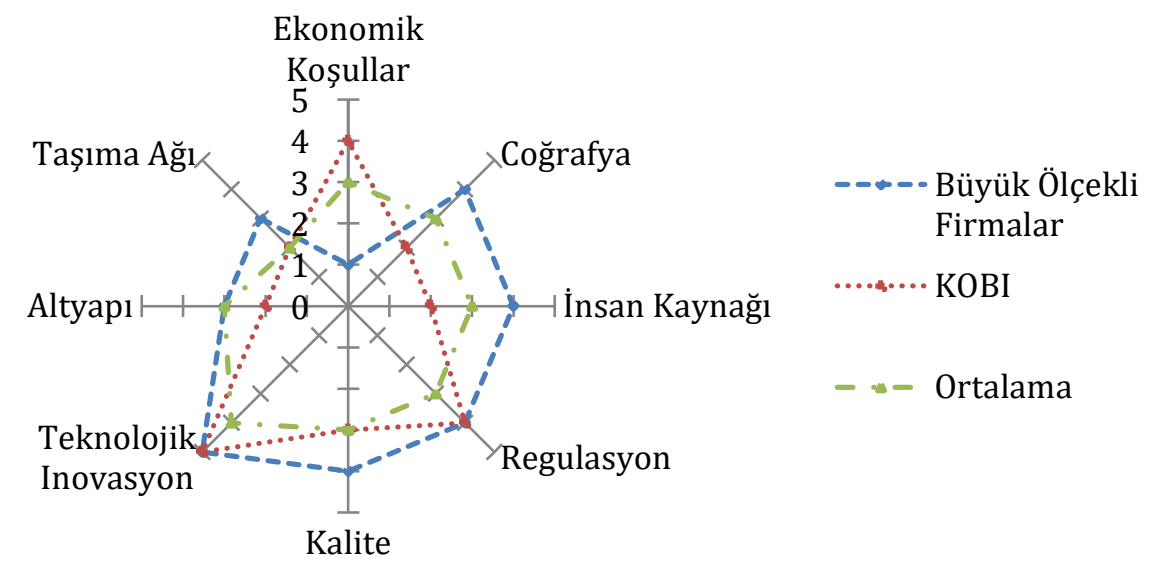

Şekil 6: Anket Cevaplarının Firma ve Katılımcı Ölçeğinde Karşılaştırılması

\section{Bulgular}

$\mathrm{Bu}$ bölümde araștırma modelinde yer alan değişkenlerin birbirleri ile olan etkileşimlerini ve çıan sonuçların kalitesi üzerine analizlere yer verilmiştir. Hazırlanan hipotezlerin sonuçlara olan etkileri detaylı bir şekilde değerlendirilerek, aralarındaki ilişkiler ortaya çıkarılmaya çalışılmıştır. Yapılan çalışmada modelin ölçme değişmezliği 3 farklı hiyerarşik seviyede yapılmıştır: Yapısal, Metrik ve Skalar. Kurulmuş olan modelin geçerliliği için öncelikle her bir ara katman (Eğitim ve Öğrenme; Bilgi Paylaşımı) ve çıktı değişkenleri ayrı ayrı test edilmiştir. $\mathrm{Bu}$ aşamada elde edilen uyumlu bir başlangıç modeli karşılaștırmalarda kullanılmak üzere hazırlanmıștır.

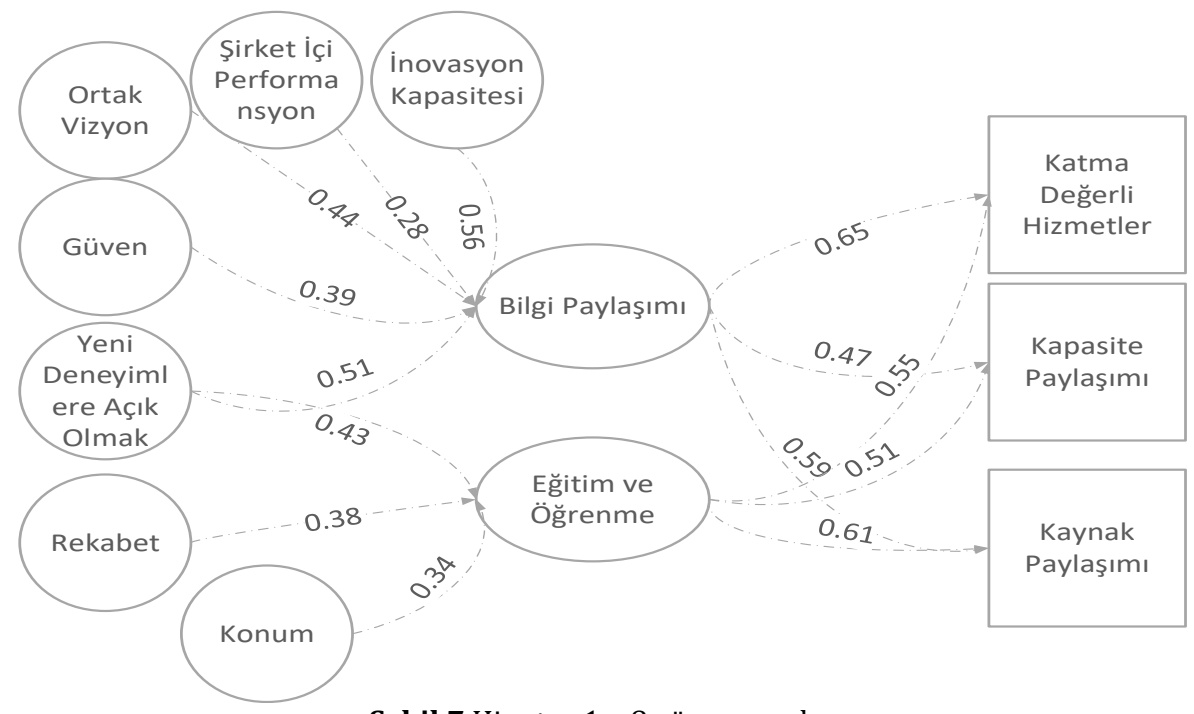

Şekil 7.Hipotez 1 - 8 göre sonuçlar

Şekil 7'de çeșitli katmanların birbirleri ile olan uyum değerlerine yer verilmiștir. $\mathrm{Bu}$ değerlerin 1 değerine yaklaşması aralarındaki uyumun ve ilişkinin kuvvetini göstermektedir. Bu bağlamda Şekil 7'de belirtildiği üzere sektör 
paydaşlarının inovasyon kapasitelerinin yüksek olması (0.56) ve yeni deneyimlere açık olmaları (0.51) bilgi paylaşımı süreçlerini çok daha olumlu yönde etkilemektedir. Aynı şekilde, rekabet (0.38) ve yeni deneyimlere açı olmak (0.43) firmaların eğitim ve öğrenme kabiliyetleri üzerine fayda sağlamaktadır. Ancak, eğitim ve öğrenme üzerine elde edilen etkileşim değerleri diğer değişkenlere nazaran düşük seviyelerde kalmıştır. Özellikle şirketlerin yeni deneyimlere açı olması eğitim ve öğrenme kabiliyetlerinin geliştirilmesi için en kuvvetli değişken olarak ön plana çıkmaktadır. Sektör paydaşları arasında bilgi paylaşımının artması (0.65) en çok katma değerli hizmetlerin artmasını desteklemektedir ve kaynak paylaşımı üzerine de ciddi katkıları vardır. Eğitim ve öğrenme faaliyetleri $(0.61)$ ise firmaların kaynaklarını ortak havuzda paylaşmalarına ve oradan kullanmalarına destek olmaktadır. Yine kapasite paylașımı ve katma değerli hizmetlerin artırılması süreçlerinde de önemli faydasının olduğu gözlenmiștir

Tablo 2.Modele ait test istatistik sonuçları

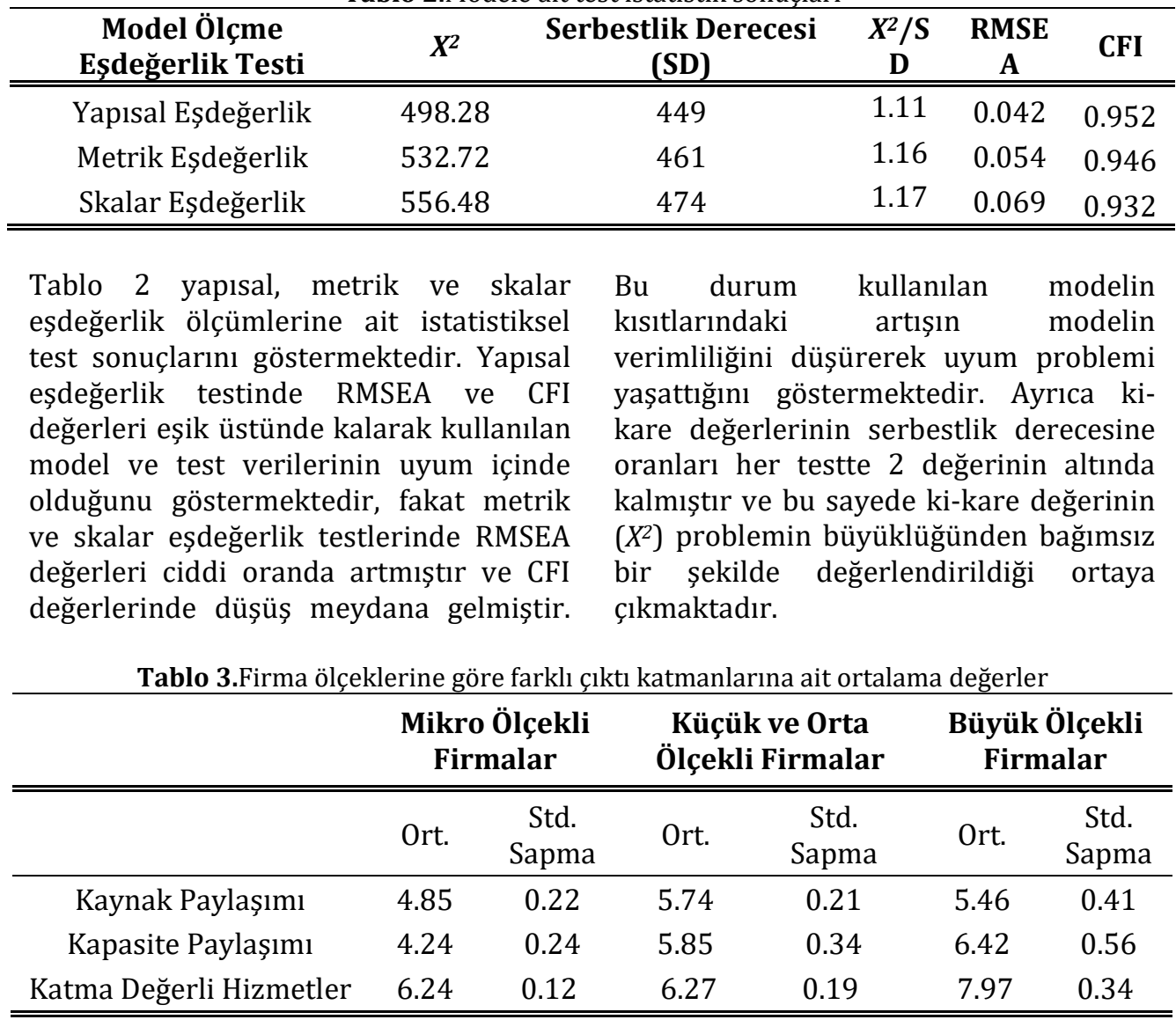

Tablo 3'de de görüldüğü üzere firma ölçeklerine göre çıktı değişkenlerinin almış oldukları ortalama değerlerde bazı değișimler olduğu gözlenmiștir. Tablo 3'de yer verilen değerler sektör paydaşlarının vermiş olduğu cevapların ölçme değişmezliği testine tabi tutulduğu zaman ortaya çıkan dağılım grafiğinin ortalama değerlerini ve dağılım fonksiyonuna göre standart sapmalarını 
göstermektedir. Saha çalışmasından elde edilen veriye göre büyük ölçekli firmaların kapasite paylaşımına ve katma değerli hizmetlerin artırılmasına yönelik çalışmalara çok daha olumlu baktıklarını ancak kaynak paylaşımında küçük ve orta ölçekli firmaların daha yatkın oldukları gözlenmiștir. Veri setlerinden elde edinilen veriler doğrultusunda genel anlamda firma ölçeği büyüdükçe, firmaların kapasite paylaşımına ve katma değerli hizmet üretilmesine olan eğilimi artmaktadır, ancak katma değerli hizmetler kapsamında mikro, küçük ve orta ölçekli firmalarda benzer bir eğilim olduğu gözlenmiştir. Ayrıca, kapasite paylaşımında büyük ölçekli firmalar mikro ölçekli firmalara nazaran daha destekleyici olmalarına rağmen küçük ve orta ölçekli firmalara nazaran geride kalmışlardır.

Tablo 4.Paydaș tiplerine göre farklı çıktı katmanlarına ait ortalama değerler

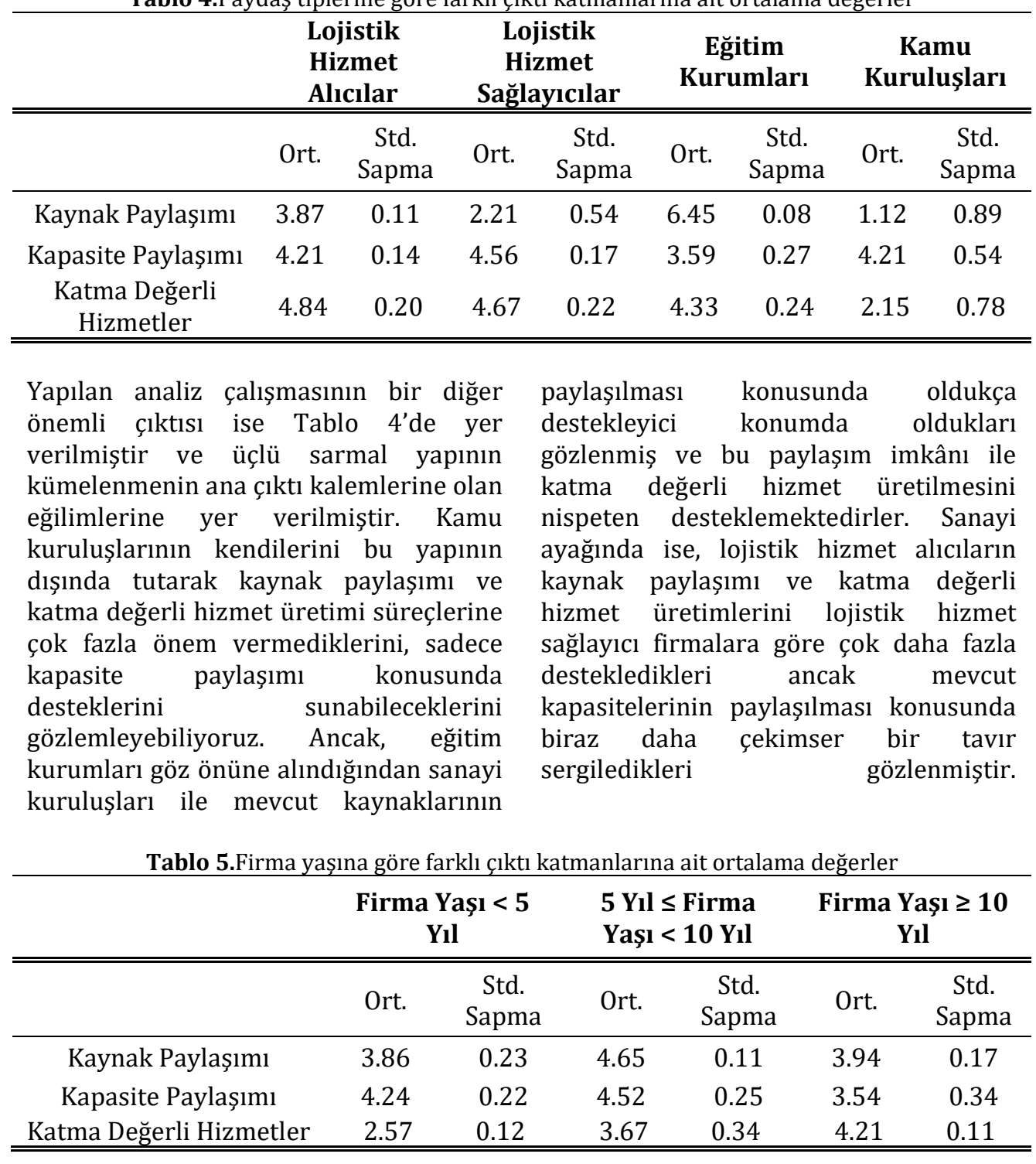


Tablo 5'de paylaşıldığı üzere kümelenme faaliyetlerinin çıktı değişkenleri üzerinde firma yaşlarının önemli bir etkisinin olduğu gözlenmiştir. Firma yaşı olarak orta sınıfta olan firmaların ( 5 - 10 yıllık) kaynak ve kapasite paylaşımı, katma değerli hizmet üretimi konusunda çok önemli desteklerinin olduğu gözlenmiştir. 10 yılın üzerinde faaliyet gösteren firmalarda bu paylaşım süreçleri bir miktar düşmesine rağmen yeni kurulan firmalara nazaran çok iyi konumda oldukları gözlenmiştir, ancak sektörün ihtiyaç duyduğu katma değerli hizmetlerin üretilmesi konusunda uzun yllardır sektörde faaliyet gösteren firmaların önemli desteklemelerinin olduğu gözlenmiştir.

\section{Tartışma ve Sonuç}

Günümüz rekabet koşullarında firmaların bulundukları pozisyonları korumaları ve daha üst bir pozisyona ulaşabilmeleri için yeni fikirler, süreçler ve sistemlerin içerisinde yer almaları ve sürekli bir gelişim trendi içerisinde olmaları gerekmektedir. Kümelenme faaliyetleri ise firmaların veya kuruluşların bilgiye, teknolojiye ve yeniliklere ulaşmalarının ve geliştirmelerinin en kolay ve hızlı yolu olarak ortaya çıkmaktadır. Yapılan saha araştırmalarında lojistik süreçlerin geliştirilmesi, sürdürülebilir ve çevreci bir form kazanması için gerekli olan tecrübe ve bilgi birikimi yerinde gözlemlenerek sektör paydaşlarının da etkin bir şekilde sürecine dâhil edildiği bir çalışma ortaya konmuștur. Yapılan çalışmada lojistik sektöründe yer alan ve üçlü sarmal yapıya dahil olan farklı paydaşlar entegre edilmiștir ve sektörün bilgi paylaşımı ve eğitim/öğrenme faaliyetlerini destekleyen 8 farklı hipotez ortaya konulmuştur. $\mathrm{Bu}$ hipotezlerin şirketlerin kapasite, kaynak paylaşımı ve katma değerli hizmet üretimine olan etkileri deneysel bir model üzerinden test edilmiş ve farklı kıstaslar doğrultusunda analizleri yapılmıştır. Elde edilen veriler ışığında şirketlerin sektör içerisindeki kapasite artışları veya firmaların çalışma yaşlarındaki artış çıktı değișkenleri üzerinde ciddi olumlu etkileri olduğu gözlenmiștir. Özellikle 510 yll arasında faaliyet gösteren büyük ölçekli firmaların kaynak, kapasite paylaşımı ve katma değerli hizmet üretimi konularında önemli desteklerinin olduğu gözlenmiştir. Bolu ilinde faaliyet gösteren firmaların büyük bir çoğunluğunu oluşturan küçük ve orta ölçekli firmaların ise büyük ölçekli firmaları takip ettikleri ve kaynak paylaşımı konusunda onlara nazaran çok daha destekleyici oldukları gözlenmiştir. Ancak, çalışma kapsamında Bolu ili için lojistik sektörüne yönelik ciddi bir katılım ile araştırma yapılmış olmasına rağmen araştırma bulgularının Türkiye lojistik sektörü için genellenebilirlik özelliği göreceli olarak düşük kalmaktadır.

Yapılan analizlerin bir diğer önemli çıktısı ise üçlü sarmal yapının önemli ayağı olan kamu kuruluşlarının kümelenme faaliyetlerinde kendilerini çok fazla sürece dâhil etmeden çıktı değișkenleri üzerine ciddi desteklerinin olmadığı gözlenmiş̧tir. Bu durum aslında Türkiye'deki kümelenme faaliyetlerinin eksik kalan bir tarafını ortaya çıkarmaktadır. Eğitim kurumları ayağında ise sektörün ellerindeki kaynakları en üst seviyede kullanarak lojistik sektörü için önemli çıktılar ve kazanımlar sağlamak istedikleri gözlenmiştir. Çalışmanın bir sonraki aşamasında bölgesel düzeyden çıkarak ulusal bir kümelenme strateji yaratılmaya çalışılacaktır. Daha geniş bir veri havuzu üzerinden analizler yapılarak, saha çalışmaları niteleyici yöntemlerle desteklenerek elde edilecek olan çıktıların ulusal kümelenme stratejisi için önemli bir yol haritası sağlaması çalışılacaktır. 
Hamdi Giray Resat / Tedarik Zinciri Yönetiminde Lojistik Kümelerin Önemi: Bolu İli İçin Uygulama

\section{Kaynaklar}

[1]. TIS - 2023 Türkiye İhracat Stratejisi ve Eylemi. 2012.

http://www.resmigazete.gov.tr/eskil er/2012/06/20120613-31-1.pdf Erișim Tarihi (11.02.2017).

[2]. Beamon, B. M., Designing the green supply chain. $1999 . \quad$ Logistics information management, 12 (4), 332342.

[3]. Zhu, Q., Sarkis, J., Lai, K. H. 2008. Confirmation of a measurement model for green supply chain management practices implementation. International journal of production economics, 111(2), 261273

[4]. Carter, C. R., Kale, R., Grimm, C. M. 2000. Environmental purchasing and firm performance: an empirical investigation. Transportation

Research Part E: Logistics and Transportation Review, 36(3), 219228.

[5]. Masoumik, S. M., Abdul-Rashid, S. H., Olugu, E. U., Raja Ghazilla, R. A. 2014. Sustainable supply chain design: A configurational approach. The Scientific World Journal.

[6]. Pishvaee, M. S., Torabi, S. A., Razmi, J. 2012. Credibility-based fuzzy mathematical programming model for green logistics design under uncertainty. Computers \& Industrial Engineering, 62(2), 624-632.

[7]. Marshall, A. 1898. Principles of economics. Vol. 1.

[8]. Porter, M. E. 1998. Cluster and the new economics of competition.

[9]. Liu, C. L., Lyons, A. C. 2011. An analysis of third-party logistics performance and service provision. Transportation Research Part E: Logistics and Transportation Review, 47(4), 547-570.

[10]. Awasthi, A., Chauhan, S. S. 2012. A hybrid approach integrating Affinity Diagram, AHP and fuzzy TOPSIS for sustainable city logistics planning.
Applied

Mathematical

Modelling, 36(2), 573-584.

[11]. Aktas, E., Agaran, B., Ulengin, F., Onsel, S. 2011. The use of outsourcing logistics activities: The case of turkey. Transportation Research Part C: Emerging Technologies, 19(5), 833852.

[12]. Jane, C. C. 2011. Performance evaluation of logistics systems under cost and reliability considerations. Transportation

Research Part E: Logistics and Transportation Review,47(2), 130137.

[13]. Ramanathan, R. 2010. The moderating roles of risk and efficiency on the relationship between logistics performance and customer loyalty in e-commerce. Transportation Research Part E: Logistics and Transportation Review, 46(6), 950962.

[13]. Yoon, K. B., Kim, H. S., Sohn, S. Y. 2008. An air force logistics management index for effective aircraft operation. Transportation Research Part E: Logistics and Transportation Review, 44(6), 11881204.

[14]. Ishfaq, R., Sox, C. R. 2010. Intermodal logistics: The interplay of financial, operational and service issues. Transportation Research Part E: Logistics and Transportation Review, 46(6), 926-949.

[15]. Rivera, L., Sheffi, Y., Knoppen, D. 2016. Logistics clusters: the impact of further agglomeration, training and firm size on collaboration and value added services. International Journal of Production Economics.

[16]. Van Den Heuvel, F., Langen, P., Van Donselaar, K. Fransoo, J. 2012. Proximity matters: synergies through co-location of logistics establishments. Beta Working Paper Series, 380.

[17]. Schuldt, A., Werner, S. 2007. Distributed clustering of autonomous 
shipping containers by concept, location, and time. Multiagent System Technologies. Springer, Berlin, Heidelberg, pp. 121-132.

[18]. Jing, N., Cai, W. 2010. Analysis on the spatial distribution of logistics industry in the developed East Coast Area in China. Ann. Reg. Sci. 45 (2), 331-350.

[19]. Lam, H.Y., Choy, K.L., Ho, G.T., Cheng, S., Lee, C. 2015. A knowledgebased logistics operations planning system for mitigating risk in warehouse order fulfillment. Int. J. Prod. Econ. 170, 763-779.

[20]. Czuchry, A., Yasin, M., Khuzhakhmetov, D. 2009. Enhancing organizational effectiveness through the implementation of supplier parks: the case of the automotive industry. J. Int. Bus. Res. 8 (1), 45-61.

[21]. Sako, M. 2003. Governing Supplier Parks: Implications for Firm Boundaries and Clusters. University of Oxford.

[22]. Musso, F. 2013. Is industrial districts logistics suitable for industrial parks? Acta Univ. Danub. 9 (4).

[23]. Resat, H. G., Turkay, M. 2015. Design and operation of intermodal transportation network in the Marmara region of Turkey. Transportation Research Part E: Logistics and Transportation Review, 83, 16-33.

[24]. Pateman, H., Cahoon, S., Chen, S., The role and value of collaboration in the logistics industry: an empirical study in Australia. Asian J. Shipp. Logist. 32 (1), 33-40, 2016.

[25]. Sheffi, Y. 2012. Logistics Clusters: Delivering Value and Driving Growth. MIT Press, Cambridge, MA.

[26]. Kam, B.H., Tsahuridu, E.E., Ding, M.J. 2010. Does Human Resource Management Contribute to the Development of Logistics and Supply Chain Capabilities? An Empirical Study of Logistics Service Providers in
China, Research and Practice in Human Resource Management, vol. 18,2 , pp. 15-34.

[27]. Lannone, F. 2012. The private and social cost efficiency of port hinterland container distribution through a regional logistics system. Transp. Res. Part A 46, 1424-1448.

[28]. Reichhart, A., Holweg, M. 2008. Colocated supplier clusters: forms, functions and theoretical perspectives. Int. J. Oper. Prod. Manag. 28 (1), 53-78.

[29]. Grando, A., Belvedere, V. 2006. District's manufacturing performances: a comparison among large, small-to-medium-sized and district enterprises. Int. J. Prod. Econ. 104 (1), 85-99.

[30]. Soinio, J., Tanskanen, K., Finne, M. 2012. How logistics-service providers can develop value-added services for SMEs: a dyadic perspective. The International Journal of Logistics Management, 23(1), 31-49.

[31]. BTS-Bolu Ticaret ve Sanayi Odası, 2015.

http://www.bolutso.org.tr/hizmetler tir-karnesi/ (Erişim tarihi 16.07.2016).

[32].KGM-Karayolları Genel Müdürlüğü, 2016.

http://www.kgm.gov.tr/SiteCollectio nDocuments/KGMdocuments/Istatist ikler/TrafikveUlasimBilgileri/15Trafi kUlas\%C4\%B1mBilgileri.pdf. (Erişim tarihi 16.07.2016).

[33].MARKA-Doğu Marmara Kalkınma Ajansl, 2016. http://www.marka.org.tr/uploads//F iles/MarkaBolgePlani/DoguMarmara BolgePlani.pdf. (Erişim tarihi 16.07.2016).

[34].BTS-Bolu Ticaret ve Sanayi Odası, 2015b.

http://www.bolutso.org.tr/dosyalar/ 2015001 DisTicaretSektorAnalizRap oru 20150112_01.pdf. (Erişim tarihi 16.07.2016). 
[35]. SPSS, I. 2011. IBM SPSS statistics for Windows, version 20.0. New York: IBM Corp.

[36]. Resat, H. G. 2015. Bolu ili gecici depolama tesisi fizibilite ve analiz raporu. Bolu Ticaret ve Sanayi Odası, Bolu.

[37]. Cronbach, L. J. 1951. Coefficient alpha and the internal structure of tests.psychometrika, 16(3), 297-334.

[38]. Brown, R. F., Schutte, N. S. 2006. Direct and indirect relationships between emotional intelligence and subjective fatigue in university students.Journal of Psychosomatic Research, 60(6), 585-593.

[39]. Cheung, G. W., Rensvold, R. B. 2002. Evaluating goodness-of-fit indexes for testing measurement invariance. Structural equation modeling,9(2), 233-255.

[40]. Millsap, R. E., Olivera-Aguilar, M. 2012. Investigating measurement invariance using confirmatory factor analysis. Handbook of structural equation modeling, 380-392.

[41]. Byrne, B. M., Shavelson, R. J., Muthén, B. 1989. Testing for the equivalence of factor covariance and mean structures: The issue of partial measurement invariance. Psychological bulletin, 105(3), 456.

[42]. Steenkamp, J. B. E., Baumgartner, H. 1998. Assessing measurement invariance in cross-national consumer research.Journal of consumer research, 25(1), 78-90.

[43]. LIKERT, R., ROSLOW, S., MURPHY, G. 1934. "A Simple and Reliable Method of Scoring the Thurstone Attitude Scales". The Journal of Social Psychology, USA.

[44]. Rigdon, E. E. 1996. CFI versus RMSEA: A comparison of two fit indexes for structural equation modeling. Structural Equation Modeling: A Multidisciplinary Journal, pg. 369-379. 